\title{
Gabonese French Dictionaries: Survey and Perspectives*
}

\author{
Paul Achille Mavoungou, Département des Sciences du Langage, \\ Université Omar Bongo, Libreville, Gabon \\ (moudika2@yahoo.fr)
}

\begin{abstract}
This article is a survey study of lexicographic activities with regards to the French language as it is spoken in Gabon, a French-speaking country in central Africa. The French language as it is spoken in Gabon does not only refer to Gabonisms (mostly items derived from native Gabonese languages), but also to standard French, official French (acrolectal level), common French (mesolectal level) and popular French (basilectal level). All four levels are present in French as it is used in Gabon. In other words, the Gabonese have named the realities of their own environment with lexical items coined on their own soil or borrowed from other languages. This has strengthened and enriched French as it is spoken in Gabon. The modern era of Gabonese lexicography has witnessed the production of various dictionaries focusing on this African variety of French. Before 1999, in Gabon and due to the status of French as the sole official language of the country, French dictionaries used in Gabon were mostly French products. Monolingual French dictionaries produced in Gabon by Gabonese scholars include a very limited number of authors, namely: Dodo Bounguendza (2008), Ditougou (2009) and Moussounda Ibouanga (2011).

Despite the fact that these dictionaries were compiled for use by Gabonese, they are differential as they tend to include references of the Parisian standard French. Indeed, a differential dictionary is a dictionary focusing on differences between two language varieties or two similar languages, and current Gabonese French dictionaries are by all means differential. It is this situation, and the ways it can be corrected that this article will focus on. The idea is to produce a complete dictionary of variant B, namely Gabonese French. Such a dictionary will reflect certain emancipation from the French language spoken in France (i.e. Parisian standard French), herein referred to as variant A.
\end{abstract}

Keywords: GABONESE FRENCH, DIFFERENTIAL DICTIONARIES, EMANCIPATION, STANDARD FRENCH, GABON

Résumé: Les dictionnaires du français du Gabon: État des lieux et perspectives. Cet article fait le point sur les activités lexicographiques en ce qui concerne la langue française telle qu'elle est parlée au Gabon, un pays francophone de l'Afrique centrale. La langue française telle qu'elle est parlée au Gabon ne fait pas seulement référence aux gabonismes (majoritairement des termes dérivés des langues gabonaises locales), mais également au français standard, au français official (niveau acrolectal), au français commun (niveau mésolectal) et au français populaire (niveau basilectal). Tous les quatre niveaux sont présents dans le français qu'il est utilisé au

* This article was presented as a keynote address at the Seventeenth Annual International Conference of the African Association for Lexicography (AFRILEX), which was hosted by the Department of African Languages, University of Pretoria, Pretoria, South Africa, 2-5 July 2012.

Lexikos 23 (AFRILEX-reeks/series 23: 2013): 255-272 
Gabon. En d'autres termes, les Gabonais ont nommé des réalités de leur propre environnement avec des termes forgés sur leur propre sol ou empruntés à d'autres langues. Ceci a renforcé et enrichi le français tel qu'il est en usage au Gabon. L'ère moderne de la lexicographie gabonaise atteste de la production de différents dictionnaires se focalisant sur cette variété africaine du français. Avant 1999, au Gabon et en raison de la situation du français comme unique langue officielle du pays, les dictionnaires français utilisés au Gabon étaient pour la plupart des produits français. Les dictionnaires monolingues français produits au Gabon concernent un nombre très limité d'auteurs, à savoir: Dodo Bounguendza (2008), Ditougou (2009) et Moussounda Ibouanga (2011).

Malgré le fait que ces dictionnaires ont été compilés pour être utilisés par les Gabonais, ils sont différentiels car ils ont tendance à inclure des références à la norme parisienne du français. En effet, un dictionnaire est dit différentiel s'il met l'accent sur les différences entre les deux variétés d'une même langue ou de deux langues similaires et actuellement les dictionnaires du français du Gabon sont tous des ouvrages différentiels. C'est cette situation et les moyens de la corriger qui constituent l'objet du présent article. L'idée est de produire un dictionnaire complet de la variante $\mathrm{B}$, à savoir: le français du Gabon. Un tel dictionnaire sera le reflet d'une certaine émancipation du français du Gabon par rapport à la langue française parlée en France, autrement dit le français de Paris, langue standard ou norme appelée variante A.

Mots-clés: FRANÇAIS DU GABON, DICTIONNAIRES DIFFÉRENTIELS, ÉMANCIPATION, FRANÇAIS STANDARD, GABON

\section{Introduction}

Nowadays French is geographically spread across a significant number of continents and countries. The geographical dispersal of French has brought the language into daily contact with new usages in Europe (Switzerland, Belgium, Luxemburg), in North America (Canada, Louisiana), in Africa (Senegal, Ivory Coast, Republic of the Congo, etc.), in Asia (Vietnam, Cambodia, Laos) and in the Middle East (mainly Lebanon). This has strengthened and enriched the French language as it is spoken in France. It is very important that dictionaries should give an account of the usage of French spoken outside the Hexagon, especially as it influences the form used in France. In any dictionary, the focus should be on one variety of a given language. But when including lexical items restricted to a variety exclusively used by the target users of the dictionary, the lexicographer should indicate this restricted usage by employing a system of geographical labels. A number of geographical labels are used in dictionaries, namely: Briticisms, Americanisms, Canadianisms, Quebecisms, Belgicisms, Africanisms and so on. The distinct nature of English varieties outside Britain has become an acceptable phenomenon. English dictionaries produced in America (American English), Canada (Canadian English), New Zealand (New Zealand English), South Africa (South African English), and so on are part of the world's dictionary landscape. Quite differently, French dictionaries produced outside France are hardly given a warm reception. Let us just mention the case of the lexicographic revolution in Quebec. The lukewarm, not to say openly hostile reception of the Dictionnaire québécois d'aujourd'hui (DQA), 
edited by Jean-Claude Boulanger (1992) and supervised by Alain Rey of the Robert publishing house, is an example in this regard.

Since its introduction, French has been used in Gabon for more than 150 years and is no longer just a foreign language but also a native language, a second language and an international language. The severe colonial French language policy prohibited the use of any native language in the public domain (KwenziMikala 1990: 122) and ultimately led to the decay of native languages. Gabon is linguistically diverse; the amalgamation of the many ethnic groups (approximately 40) of the country was made possible by a common language: French. Originally it was the language of the conqueror, but it also became the true lingua franca of the country as well as the language of national unity after the country's independence in 1960. Since colonial times, the French language in Gabon has developed in various fascinating ways. A vivid national identity had been created. Subtle nuances and colourful images have appeared in Gabonese French.

This article seeks to reflect on the survey of Gabonese French dictionaries and lexica as well as concrete projects that are currently undertaken in order to improve the development of the variety of the French language spoken in Gabon. The whole is concluded by some ideas about the way to proceed in future.

In order to better understand the history of the compilation of French dictionaries and lexica in Gabon, it is important to go back to the roots of this dictionary production, especially with the arrival of the Europeans in Gabon.

\section{The history of the French language in Gabon and bilingual dictionar- ies pairing French with indigenous languages}

The first contact with Europeans was with the Portuguese in the fifteen century. During the following 350 years, first the Portuguese and later the French, Dutch, and the English carried on a lucrative trade in slaves from Gabon. The first permanent European settlement was made by the French, with the «agreement» of the Mpongwe ruler, in 1839. Libreville was founded a decade later by freed slaves. The French gradually extended their rule inland, and in 1866 appointed a governor to Gabon, which was then attached to the French Congo; it became part of French Equatorial Africa in 1910 (Encarta 1993-2000). After the attainment of independence, Gabon adopted the language of the former colonial master for functional purposes in official circles.

As far as lexicography is concerned, two eras of dictionary production in Gabon can be distinguished: the earlier era and the modern era. The early bilingual dictionaries in Gabon were compiled by missionaries and colonial officials and were to serve as reference works for European traders and French colonial administrators in their daily routine. These dictionaries can therefore be regarded, according to Gouws (2007: 314), as externally motivated products. Contrary to these dictionaries compiled by "foreigners", the modern era starts from 2002 with the publication of Gedandedi sa geviya/Dictionnaire geviya-français by Van der Veen and Bodinga-Bwa-Bodinga. The appearance of this dictionary opens a new era of dictionary publication in Gabon. As a matter of fact, it has 
formed the basis for further lexicographic projects directed at the needs of the speech communities of Gabon (Mickala Manfoumbi 2004; UNESCO-LUTO 2006; Mavoungou and Plumel 2010; Idiata and De Nadaillac 2010). These new lexicographic products are intended to enhance the communicative abilities of the Gabonese speech communities and can therefore be regarded, according to Gouws (2007: 314-315), as internally motivated products. Moreover, Ella (2011, 2012) has discussed the compilation of Gabonese French dictionaries by showing that standard French dictionaries have to be adopted to fulfil the needs of the way French is spoken in Gabon.

\section{Gabonese Language Landscape (GLL)}

Ndinga-Koumba-Binza (2005a, 2005b, and 2007) indicated that the Gabonese language landscape refers to both foreign and local languages spoken in the country. The latter group comprises French, the sole official language, and the native languages.

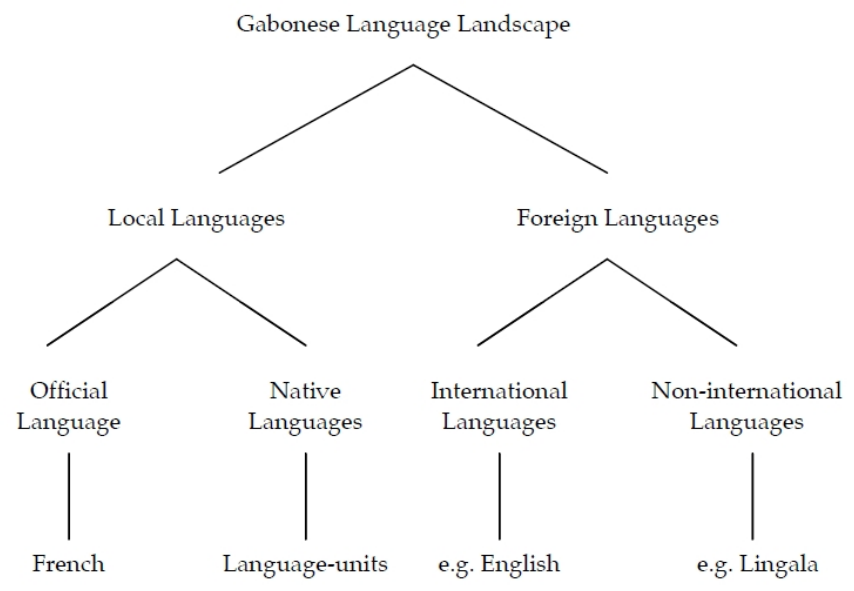

Source: Ndinga-Koumba-Binza (2005a: 134)

With the exception of some languages of the pygmies, all Gabonese heritage languages are Bantu and they are to be found in zones A, B and H of Guthrie's referential classification (Guthrie 1953). Some of these languages are more dynamic than others. A sizeable number of Gabonese heritage languages falls within Fishman's (1991) stages 7 (i.e. they are used for cultural events and ceremonies), 6 (i.e. children are learning the language from their parents, neighbourhood, and communities) and 5 (i.e. there is local literacy in the community, and literacy programmes in the native languages), while others are unfortunately at stage 8 (i.e. they are close to extinction). So far no Gabonese heritage language falls within Fishman's (1991) stages 4 (i.e. the language is used in 
school), 3 (i.e. the language is used in the work sphere), 2 (the language is used in the local mass media, and local government) and 1 (i.e. the language exists at the highest levels in government, the universities, and national media). There is no standard language among the Gabonese heritage languages. "Standard language" is used here in the sense of a form or variety of any given language, "which is learned and accepted as correct across a community or set of communities in which others are also used" (Matthews 1997: 352). None has any constitutional status, nor is there any that is specifically mentioned in the Gabonese Constitution. The revised Constitution of 1994 (Art. 2, par. 8) simply committed the Republic to "endeavor to protect and promote national languages" without indicating which, and how, when, and in which order this should be done, nor to what extent (Emejulu 2000: 57-58 and 62). Finally, on the national level, there is no one dominant heritage language.

\section{Varieties of French}

One important dimension which determines language variety is the regional distribution of particular linguistic forms. In the case of French, a distinction can be made between:

- National varieties such as French spoken in France, Swiss French, Senegalese French, Gabonese French, etc., and

- Regional dialects, which are regional varieties within a national variety, such as Marseille French, Libreville French or Dakar French.

While there are many varieties of African French, common features include the use of an alveolar trill and the use of borrowed words from local languages. Four variants of French in Gabon can be distinguished, namely: standard French, official French (acrolectal level), common French (mesolectal level) and popular French (basilectal level).

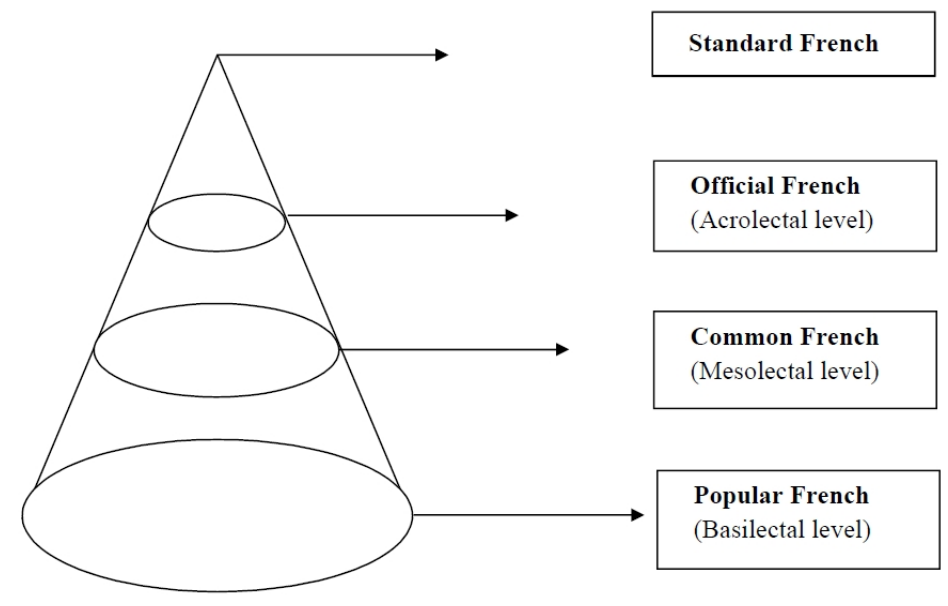


Official French is the language of administration, schools, and all official circles. This variety is very close to Metropolitan French (spoken in Paris and considered standard). This French has been codified by centuries of dictionarymakers, grammar-book writers, printers and publishers, and educational systems.

Common French is very rich in Gabonisms. Gabonese people have named realities of their own environment with lexical items coined on their own soil or borrowed from other languages. They borrow words directly from local languages or they literally translate, often unknowingly, phrases or constructions from local languages.

Popular French, in which linguistic liberties are many, attests to the social life and the contemporary linguistic history of Gabon. This is a delightful language, full of different accents and mother-tongue interference.

Common French and popular French are not standardized or normalized and they are therefore excluded from the school and administrative spheres.

Gabonese French (cf. Boucher and Lafage 2000: XXIX-XXX) is a repertoire of a variety of lexical items and expressions. Idiosyncratic features of Gabonese French in vocabulary and syntax are presented below:

- Archaic, obsolete or old usage: canguer (to catch red-handed) rather than standard French enchainer (to chain up);

- Abbreviation (a process of shortening a compound by using the initial letters of the words which are pronounced separately): P.K. (kilometric point) rather than standard French point kilométrique (kilometric point), D.V.D. ("Dos Ventre Dehors") and V.C.D. ("Ventre Cul Dehors") which are misappropriations of Digital Versatile Disk and Video Compact Disk pejoratively used to designate sexy young women and prostitutes, clando rather than standard French taxi clandestine or taxi brousse (bush taxi), rapido (sexual intercourse in a car with a prostitute);

- Modification of fixed expressions: Quand les poules auront des dents et des cornes au menton (and pigs might fly) rather than standard French quand les poules auront des dents;

- Usual graphic modification: bonané rather than standard French bonne année (happy New Year);

- Change of connotation: charlatan (ameliorative for "a traditional healer"), cascadeur (pejorative for "a young man whose carelessness can be lifethreatening to others");

- Change of denotation: bureau (a woman who is kept by a married man), caïman (a crocodile), sanglier (a bush pig);

- Loan words from Gabonese languages: musomfi (a woman who has just given birth to a child), nganga (a traditional healer or sangoma), safou (the edible fruit produced by the safoutier);

- Anglicisms: tchatcher (to chat, to converse), tchatcheur (a good speaker); 
- Neologisms: buflon (young buffalo), dédeuillement (the ending of the mourning period), fétichisme (fetishism), tresseuse (a female who plaits), marabout (a sangoma), maraboutisme (the craft of the sangoma), marabouter (to act as a sangoma), se saper (to dress elegantly), sapeur (an elegant person), absenter (to miss someone), grever (to be on strike), siester (to take a nap), régler (to have menstrual periods), tôler (to cover a house with corrugated iron), têter (to play a header with a soccer ball), etc.

\section{Existing Gabonese French dictionaries}

For many years, the general vocabulary of French as it is spoken in Gabon has been represented in the so-called bilingual externally motivated dictionaries that often had a Gabonese and a European language (French) as language pair. This situation began to change toward the end of the twentieth century. From 1972 to 1983, under the auspices of AUPELF (Association of Partially or Wholly French Language Universities, Association des Universités Partiellement ou Entièrement de langue Française in French), today called the AUF (Francophone University Agency, Agence Universitaire de la Francophonie in French), an extensive lexical research programme was conducted through a number of Frenchspeaking countries of Black Africa. The project resulted in the publication in 1983 and in 1987 of a huge reference work, the Inventaire des particularités lexicales du Français en Afrique Noire (IFA). Unfortunately, Gabon did not participate in this research. To overcome this lack a number of students, French and Gabonese, embarked on this quest for their master's theses: Claudettte BoutinDousset (1989), Caroline Thibaudier (1991), Maria Alves (1994), Marie Artigues, (1995), Karine Boucher (1997, 1998, 1999), Sandrine Ntsaga-Oyouni (1998), Diane Bagouendi-Bagere (1999), Magali Italia (2000). In order to participate in the second phase of IFA, Karine Boucher wrote her M.A. dissertation (Boucher 1998) under the guidance of Suzanne Lafage. Different kinds of fieldwork were undertaken in Libreville, and collecting for this project was also done thanks to the participation of Gabonese students at the École Normale Supérieure (ENS) of Libreville. In 2000, the dissertation was published under the title: Le lexique français du Gabon (entre tradition et modernité). For this version of the work released as a special issue of the journal Le français en Afrique (Revue du Réseau des Observatoires du Français Contemporain en Afrique), issue 14, Suzanne Lafage joined in the writing. Boucher and Lafage's contribution is an alphabetically arranged lexicographic work of considerable size, consisting of 2500 articles covering 415 pages. Although the title of this publication modestly describes it as a "lexicon", it is in fact a comprehensive and thorough dictionary. The central list of Boucher and Lafage's work comprises a set of lexical items as used by the younger generation of Libreville inhabitants aged from 15 to 30. Fair attention is given to different style or normative levels, i.e. standard French, official French (acrolectal level), common French (mesolectal level) and popular French (basilectal level). Compare the following articles in this regard: 
ABÈGNE, VAR. ABÊGN, ABÈ, n.m. Dispon. (du fang "maison commune des hommes"). Maison commune, placée au bout du village où les hommes ont coutume de se réunir. V. CORPS* DE GARDE. [...] lorsque tout le monde est bien groupé dans l'abène (case* à palabre), on montre les douze images du catéchisme illustré des vérités nécessaires composé par Monseigneur Le Roy [...]. (Raponda-Walker, 1910 a: 6). Autrefois, chez les Fang, l'abègne faisait surtout fonction de corps* de garde. (Raponda-Walker/Sillans, 1983: 197). La protection s'appuyait sur les maisons communes des hommes, tel que l' "abêgn" des Fang - celles surtout qui étaient placées en bout de village - si bien que l'habitude s'est prise de les dénommer "corps* de garde". (Pourtier, t.1, 1989: 159).

SYN.: abong, banza/bandza*, case* à palabres, case* commune, case* de réunion, corps* de garde, ebanza*, mbandja*, temple du bwiti*.

\section{BOUCHER and LAFAGE (2000: 2)}

ADMINISTRATEUR, VAR. ADMINISTRATEUR DE BROUSSE, $n . m . V x$ mais encore disponible à l'écrit. V. COMMANDANT*. Fonctionnaire français de l'époque coloniale, placé à la tête d'un cercle* ou d'une subdivision. L'administrateur, souvent seul dans son poste éloigné, représente tous les éléments de l'autorité. Il est pouvoir législatif: il essaie de faire concorder les lois françaises et le code de l'indigénat* avec les bonnes coutumes* du pays. [...] Il est pouvoir judiciaire. [...] Il est chef de l'état civil [...]. Enfin il est pouvoir exécutif et justicier [...]. (Grébert, 1928: 11). Déjà je regardais en arrière le compte de mes réalisations, compte classique qui devait ressembler à celui de beaucoup d'administrateurs de brousse. (Charnay, 1983: 157).

ENCYCL.: Les administrateurs étaient issus de l'Ecole coloniale, devenue plus tard Ecole Nationale de la France d'Outremer. LOC.: administrateur de brousse. SYN.: commandant*, commandant de cercle* (A.O.F. surtout), chef de subdivision* (A.E.F, Cameroun).

\section{BOUCHER and LAFAGE (2000: 5)}

After the publication of the Lexique français du Gabon in 2000, there was a long hiatus in French-language lexicography in Gabon. In 2008, Eric Dodo Bounguendza, a Gabonese linguist, published a Gabonese French dictionary entitled Dictionnaire des Gabonismes. This dictionary has a macrostructure consisting of 765 lemmata covering 142 pages which were identified specifically as Gabonese by the author.

Assamsè n.m. Boutique de fripier.

Il a acheté ce beau pantalon à assamsè.

Fréquent, oral, écrit, tous milieux.

Bana-bana n.m. Vendeur ambulant de marchandises. Devant les grands magasins de la capitale, il y a toujours des bana-bana en quête des clients. 
Fréquent, oral, écrit, tous milieux.

\section{Eric DODO BOUNGUENDZA (2008: 23 and 29)}

Just a year later, the dictionary of Dodo Bounguendza was followed by another lexicographic work. Although entitled On est ensemble 852 mots pour comprendre le français $d u$ Gabon, this publication is in fact a fairly small lexicon of Gabonese French consisting of 852 lemmata and covering 154 pages. It was published in 2009 by Lucien Ditougou, a Gabonese scholar lecturing in the Department of African Literature at Omar Bongo University.

142- Bouche: N. f. (1) Avoir la : avoir la parole facile. Il évite une confrontation avec Musunda parce qu'elle a la bouche. (2) Avoir la même : avancer les mêmes propos sans varier. Version. Depuis qu'on l'interroge sur cette affaire, il a la même bouche. (3) Avoir la même que quelqu'un: être du même avis que lui. J'ai la même bouche que Koumba. (4) Être dans la de quelqu'un: acquiescer ce qu'il dit ou faire sienne les paroles qu'il a prononcées. Je suis dans la bouche de Ngondo. Oui, il a bien parlé. (5) Faire la : narguer; s'enorgueillir. A la tâche, Kumba ne fait plus la bouche.

\section{Lucien DITOUGOU (2009: 28)}

A sample of 23 drawings by Lybek had been included as a bonus in the linguistic treatment of Gabonese French in the lexicon (see Fig. 1, 2 and 3).

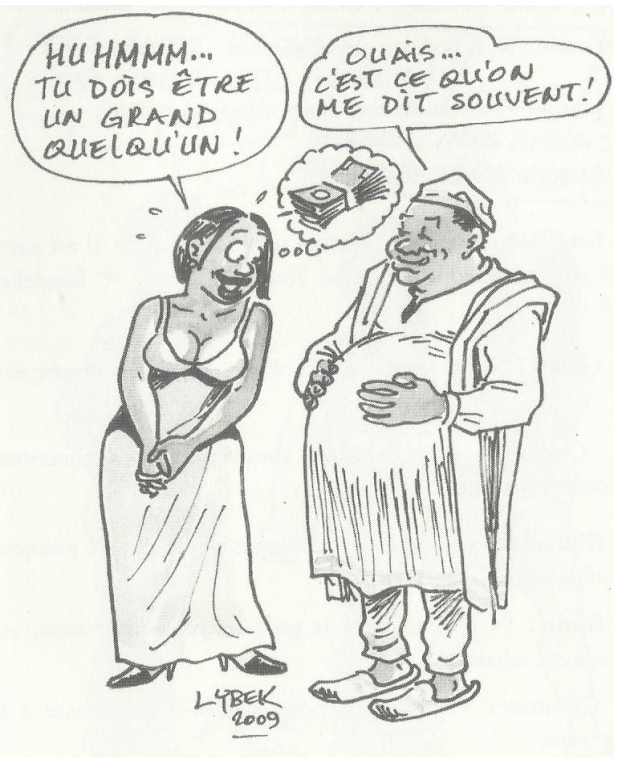

Figure 1

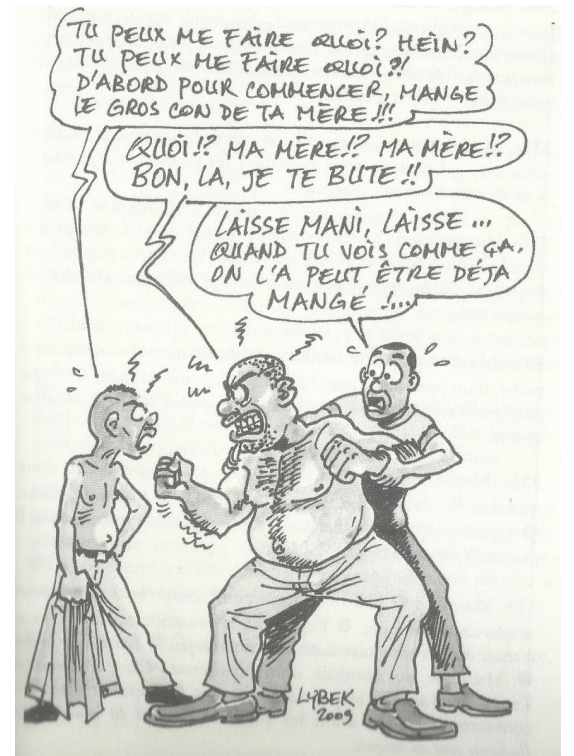

Figure 2 
The reason why Ditougou's contribution was well received by the public is that the pictorial illustrations included in the dictionary are masterpieces of Gabonese humour and self-portraiture. Lybek's drawings allowed Gabonese to recognize their own language specificity in a reference tool used not only to find the meaning or the orthography of a given lexical item but also for them to have a good laugh. As a matter of fact, many users have confessed that they bought the book in the first place for the humorous drawings. Of course, this is not part of the genuine purpose of a dictionary (cf. Wiegand 1998).

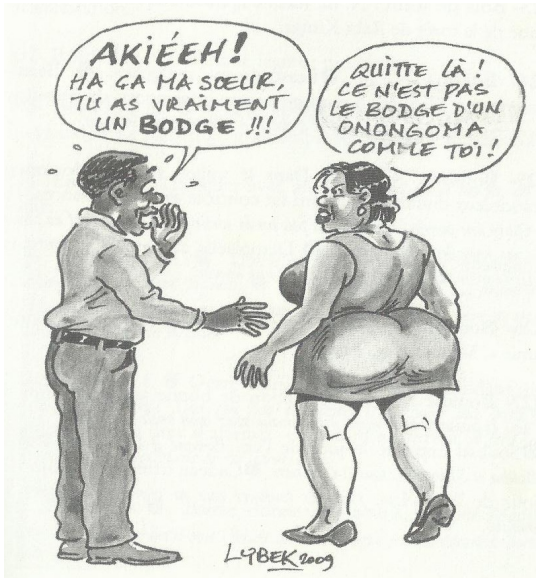

Figure 3

Dodo Bounguendza is also the author of another lexicographic work entitled Diagnostic du Français du Gabon published in 2010 as a normative product of the French language.

Cameraman D'abord il faut distinguer le «cameraman reporter» du «cameraman de plateau». Ce mot est un anglicisme et l'équivalent recommandé par la Commission de terminologie de l'O.R.T.F. est le «journaliste reporter d'images» qui est différent du «cameraman de plateau.» D'ailleurs, en français, on parle plus de cadreur. $\downarrow$ Pour couvrir cet évènement, je te suggère de prendre Olivier Antonio comme cameraman. $\uparrow$ Pour couvrir cet évènement, je te suggère de prendre Olivier Antonio comme journaliste reporter d'images.

Fréquent, citoyen ordinaire, journalistes, politiques, universitaires.

\section{Eric DODO BOUNGUENDZA (2010: 28)}

The work of Moussounda Ibouanga entitled Français du Gabon: Approches sociolinguistique et lexicographique was published in 2011. It is an alphabetically arranged monolingual lexicon consisting of 950 articles and covering 292 pages. The publication is based on several sources, its primary source being the lexicon of Karine Boucher and Suzanne Lafage (2000). 
Combi: n. c. basilecte. - Personne avec qui on a une relation fraternelle. $\boldsymbol{\Delta}$ C'est une sorte de d'amitié réciproque. Syn. Complice, pote, ami, frangin, dream team, type. Lui, c'est mon vrai combi. (Herbert, 27 ans). Oral, fréquent, milieu des jeunes. (Ce terme est absent de Boucher, 2000). [k̃̃mbi] On est ensemble: locution du basilecte. (Gabonisme). a Se dit pour renforcer et retracer la solidarité et la fraternité des Gabonais. Syn. On ne se perd pas de vue. Nous sommes ensemble. On est ensemble. (Pony, 38 ans). Oral, courant, parler commun. (Cette phrase est absente de Boucher, 2000).

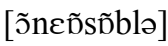

Firmin MOUSSOUNDA IBOUANGA (2011: 118 and 213)

To date the most thorough documentation of the Gabonese French vocabulary is in Boucher and Lafage's dictionary. Despite the fact that most Gabonese French lexicographic works are internally motivated products, they are still biased toward the central French of Paris. For example, when a dictionary of Gabonisms (defined as words or meanings not used in France) is produced in Gabon, the reality is that these Gabonisms are defined with regard to standard French and not with regard to French as it is spoken in Gabon. All existing Gabonese French dictionaries are implicitly regarding variant $B$ as being inferior to variant $\mathrm{A}$, that is standard French. As such, they do not express a high degree of emancipation. That is the reason why I plead for the production of a complete dictionary of variant B (the French language as it is spoken in Gabon).

\section{Planning and compilation of a complete dictionary of variant $B$, namely Gabonese French}

The idea is to produce a complete dictionary of variant B, namely Gabonese French. Such a dictionary will reflect a certain emancipation from the French language spoken in France (standard or central French, i.e. variant A). To date and as already said, all lexicographic referential work on the French language spoken in Gabon are differential lexica or dictionaries. In other words, Gabonese lexicographers and linguists working on Gabonese French do not need to define the lexicon of their language differentially. Gabonese French differs enough from standard French to be regarded as a new emerging language and not merely as a regional variety of French. Compared to French spoken in France, lexical particularities of African French-speaking countries should not be regarded as regionalisms but rather as national varieties. Moreover, a local variety of a given language is not synonymous with a national variety (Hausmann 1986: 4-5).

Gouws has rightly emphasized: "Successful joint ventures in the lexicographic practice need to be preceded by joint research in the field of theoretical lexicography, including a focus on the planning of dictionary projects." In this regard, I have discussed (cf. Mavoungou 2002) various metalexicographic crite- 
ria for the planning and compilation of the Dictionnaire du Français du Gabon (DFG). The DFG is meant to establish itself as a model for future general dictionaries of Gabonese French. It will be the first descriptive dictionary in a one volume edition to use the French spoken in Gabon as linguistic reference or norm, and will consider as "foreign" words and meanings used only in France. In what follows, I will briefly discuss various aspects regarding corpus building, national lexicographic units and their staff.

As far as the first issue is concerned, it should be mentioned that corpora used in the existing Gabonese French dictionaries are too small and crudely selected. Emejulu (2000: 62) has stressed:

\begin{abstract}
Though dialectizing rapidly, Gabonese French is not standardized, nor normalized and is excluded from the school and administrative spheres. However, it strongly attests to the social life and the contemporary linguistic history of Gabon. A comprehensive, monolingual dictionary that should be periodically updated is very necessary to keep the trend of the linguistic and anthropological evolutions of our society; a lexicographic unit is therefore needed to embark on a large-scale nationwide corpus build-up and dictionary planning.
\end{abstract}

A very important demand made on a corpus today is that it should be balanced. In other words, before embarking on any lexicographic activity, the lexicographer has to make sure that he/she has a representative corpus of the language which is to be described. This means that it should contain texts from (a) different genres, (b) spoken and written language and (c) speakers of different regions, age groups, social backgrounds and genders (Herbst 2007: 30). So far only Gabonese French as it is spoken in Libreville has been systematically documented. A survey of French as it is spoken in Port-Gentil (the centre of Gabon's petroleum and timber industries, having recently become one of the richest cities in Gabon) can be found in a Ph.D. dissertation completed at the University of Stendhal-Grenoble III by Ompoussa (2008). Another notable Ph.D. dissertation, Moussounda Ibouanga (2006), written at the University of Aix-en-Provence gives an account of Gabonese French as it is spoken in Mouila (in the south-west of Gabon). Since common and popular French are not written, the bulk of data from towns and provinces not yet been surveyed will be obtained from interviews or will consist of answers to questionnaires completed by volunteers or students. Once the information is captured, transcripts of conversations, dialogues or interviews have to be computerized in the form of a database or in the form of a corpus. To these data, material taken from older investigations or from written sources such as newspapers produced in Gabon, novels, books, and especially existing Gabonese French monolingual dictionaries as well as bilingual dictionaries pairing French with indigenous languages will be added to the database or the corpus of Gabonese French. The future editorial board of the Dictionnaire du Français $d u$ Gabon could also rely on a long tradition of African French investigation at a number of universities and institutions in France (Aix-en-Provence University, the Paris III-Sorbonne Nou- 
velle University, and so on). The idea is to document the basic vocabulary of the language (that is the core lexicon of French which is more or less identical for Gabonese and French people), the available common basic lexicon (which differs a lot between the Gabonese and the French), the scientific oriented general lexica and the highly specialized lexica (which are very much the same for specialists of the same discipline whether Gabonese or French). The pronunciation of Gabonese French lexical items will also be obtained through fieldwork. This is extremely important. Gabon has its own distinct idiosyncratic features of pronunciation, vocabulary and syntax, resulting from contact with indigenous languages. Pronunciation was omitted from Boucher and Lafage's work owing to insufficient data. This has to be corrected in the prospective Dictionnaire du Français du Gabon.

Across dictionaries, lexicographers usually experience similar problems which can be dealt with by means of similar solutions. On puristic grounds, some people are against slang words and expressions. Conscious of this fact, the future editorial board of the DFG will be well advised to carefully consider the inclusion of Gabonisms. For example, Gabrielle Saint-Yves (2001), reflecting on the reception of the Dictionnaire québécois d'aujourd'hui (DQA), wrote:

Many Quebec linguists, the Office de la langue française (OLF), and language teachers emphatically disagreed both with the selection of entries and its sociolinguistic labels. In reaction to media debates and social pressure, the Quebec Ministry of Education banned the pedagogical use of the $D Q A$ in the classroom.

If the future editorial board of the DFG feels that the public is not prepared to see slang words and expressions included in a General Monolingual Dictionary of Gabonese French, it must not be insisted that they should be included before a general consensus on a Gabonese norm could be reached. As far as this point is concerned, acceptance must be considered as most important.

With regard to the training of staff members of a dictionary project, the lack of trained lexicographers has often been a serious problem to overcome in a number of countries. In Central Africa, the Gabonese Republic is in the fortunate position that she has readily at hand quite a significant number of highly trained lexicographers. Ten Gabonese have received their doctoral degrees in lexicography at the University of Stellenbosch, South Africa. Despite the importance of this achievement, Gabon has not yet given full priority to the comprehensive planning of dictionary projects in the country. Gabon could utilize available expertise in order to produce more dictionaries for better communication. In this regard, National Lexicographic Units (NLUs) have to be established for all the ten language units of the country. In countries with established national lexicographic units, the former are generally hosted at tertiary institutions in the geolinguistic areas where the majority of first-language speakers live. Given that Gabon is a country with sixty-two indigenous languages but with French as the sole official language, a lexicographic unit is thus advisable to cater for the needs of the Gabonese regarding Gabonese French. 


\section{Prospects and challenges for French lexicography in Gabon}

Although the Gabonese language landscape displays several native languages and a number of other foreign languages (Ndinga-Koumba-Binza 2005a: 134), none has ever been made official or been used for official purposes. The fact that French is increasingly becoming the mother tongue of younger generations gives it a promising future in Gabon. In the light of the previous section, Gabonese French lexicography may be seen as a long-term but worthwhile prospect. There is a need for Gabonese French dictionaries aimed at a very specific target user. For meeting the real needs as well as the reference skills of the intended target user, the focus should be on the compilation of pedagogic or teaching materials, such as school dictionaries, grammar books and syllabi in order to reflect the linguistic usage of the French language spoken in Gabon. Coming back to the organization of the National Lexicographic Units (NLUs) of the country, these units should be managed by a board of directors under the control of a language body of which the mandate will be to legislate over important linguistic matters including the issue regarding the extraordinary stock of gentiles, toponymic adjectives, derivatives of place names, proper nouns, and other neologisms in Gabonese French which are being created by journalists, writers, laypersons and singers to express the vivid national identity of the Gabonese (Mavoungou 2011).

Kwenzi-Mikala's (1998) internal classification offers an ideal theoretical platform for establishing National Lexicographic Units. As far as this point is concerned, the Gabonese French NLU should play a vital role. Employing the hub-and-spoke model (cf. Martin 1996), the NLU for Gabonese French will be in charge of the compilation of all the monolingual dictionaries dealing with Gabonese French. The NLUs of the other Gabonese languages will be faced with at least two challenges, namely the choice of the dialect as pre-selected language and the compilation of bridging dictionaries between the particular pre-selected Gabonese language (spoke) and Gabonese French, the official language (hub). In the light of Gallardo (1980: 61), the future editorial board of the specific unit should only consider the tremendous task of compiling a comprehensive monolingual dictionary of the particular pre-selected language later on. And the first step to do so is the compilation of a database. It is also wellattested that the preparation of a database may be costly and time-consuming. Owing to the fact that most existing dictionaries of Gabonese languages have been the input of single lexicographers, future lexicographic products should be the result of team efforts.

Mavoungou (2002) and Mavoungou et al. (2002) discussed various metalexicographic criteria for the planning and compilation of the Dictionnaire $d u$ Français du Gabon (DFG). As a result of these studies, a major project involving all Gabonese lexicographers is currently under way. Gabonese lexicographers, sociolinguists and educationists have also joined forces in order to produce the first idiomatic dictionary of Gabonese French (Mavoungou, Moussounda Ibouanga and Pambou, forthcoming). 


\section{Conclusion}

The survey of Gabonese French dictionaries and lexica above shows that most dictionaries available for Gabonese French are differential products. Another feature is that corpora used in these dictionaries are too small and crudely selected. The only way to address this situation is twofold: (a) to collect spoken language at grassroots level through fieldwork, and (b) to obtain data from written sources such as newspapers produced in Gabon, novels, books, and especially existing Gabonese French monolingual dictionaries as well as bilingual dictionaries pairing French with indigenous languages in order to enlarge the database or the corpus of Gabonese French. The compilation of the DFG is answering the need for linguistic recognition and cultural autonomy. It is an attempt to go beyond all existing lexicographic products published in Gabonese French. It will represent all registers of French spoken in Gabon and will take account of all lexical items (including Anglicisms and socially banned, taboo or slang expressions) and their sociolinguistic labels. This dictionary project will only fulfil its purpose when completed. The different prospects raised above will be confronted with serious challenges ranging from financial, political to social support within and outside Gabon.

\section{References}

Alves, M. 1994. La presse gabonaise en langue française: étude lexicale. Mémoire sous la direction de S. Lafage. Paris: Université de Paris III-Sorbonne Nouvelle.

Artigues, M. 1995. Participation à une étude des particularités lexicales du français parlé au Gabon. Mémoire sous la direction de S. Lafage. Paris: Université de Paris III-Sorbonne Nouvelle.

Bagouendi-Bagere, D. 1999. Etude des procédés de néologie lexicale dans le français parlé au Gabon. Mémoire sous la direction de A. Quéffelec. Université de Provence-Aix-Marseille I.

Boucher, K. 1997. Créativité lexicale et identité culturelle du français au Gabon. Mémoire de maitrise sous la direction de S. Lafage. Paris: Université de Paris III-Sorbonne Nouvelle.

Boucher, K. 1998. Langues et identité culturelle des jeunes Librevillois de 15 à 30 ans: une enquête de terrain. Mémoire de DEA sous la direction de S. Lafage. Paris: Université de la Sorbonne Nouvelle-Paris III.

Boucher, K. 1999. Approche des représentations sociolinguistiques dans un groupe de jeunes Librevillois. Le français en Afrique 13: 173-192.

Boucher, K. 2000. "Quand tu gorges, tu blazes!" Contributions à la zè journée de l'école doctorale du 29 mai 1999, Langage et Langue, Paris III-Sorbonne Nouvelle: 55-65.

Boucher, K. and S. Lafage. 2000. Le lexique français du Gabon (entre tradition et modernité). Nice: Les presses U.F.R. Lettres, Art et Sciences Humaines de l'Université de Nice-Sophia Antipolis.

Boulanger, J.-C. (Ed.). 1992. Dictionnaire québécois d'aujourd'hui. Saint-Laurent: DicoRobert.

Boutin-Dousset, C. 1989. Matériaux pour un inventaire des particularités lexicales du français au Gabon. Mémoire sous la direction de S. Lafage. Paris: Université de la Sorbonne Nouvelle.

Charnay, R. 1983. La terre des adieux. Paris: Olivier Orban. 
Ditougou, L. 2009. On est ensemble: 852 mots pour comprendre le français du Gabon. Libreville: Éditions Raponda Walker.

Dodo Bounguendza, E. 2008. Dictionnaire des gabonismes. Paris: L'Harmattan.

Dodo Bounguendza, E. 2010. Diagnostic du français au Gabon (Guide pratique destiné aux journalistes, aux politiques, aux administratifs et aux universitaires). Libreville: Éditions Ntsame.

Ella, E.M. 2011. Typologie hybride et modèles poly-fonctionnels dans la confection des dictionnaires au Gabon. Mbaandza Revue d'étude et d'analyse francophones 1: 113-126.

Ella, E.M. 2012. Adopter un dictionnaire bilingue pour un usage local. Alac Revue Scientifique Internationale publiée par la Chaire UNESCO Interculturalité 1: 265-287.

Emejulu, J.D. 2000. Lexicography, an Economic Asset in Multilingual Gabon. Revue Gabonaise des Sciences du Langage/Gabonese Journal of Language Sciences 1: 51-69.

Encarta. 1993-2000. Gabon. Encarta Encyclopedia 2001. Microsoft Corporation.

Fishman, J.A. 1991. Reversing Language Shift: Theoretical and Empirical Foundations of Assistance to Threatened Languages. Cleveland: Multilingual Matters.

Gallardo, A. 1980. Dictionaries and the Standardization Process. Zgusta, L. (Ed.). 1980. Theory and Method in Lexicography: 59-69. Columbia: Hornbeam Press.

Gouws, R.H. 2007. Dictionaries in South Africa: Aspects of Dictionary Culture and Government Policy. International Journal of Lexicography 20(3): 313-327.

Grébert, F. 1928. Au Gabon (Afrique équatoriale française). Paris: Société des Missions Evangéliques.

Guthrie, M. 1953. The Bantu Languages of Western Equatorial Africa. Oxford: Oxford University Press.

Hausmann, F.J. 1986. Les dictionnaires du français hors de France. Boisvert, L., C. Poirier et C. Verreault (Eds.). 1986. La lexicographie québécoise: bilan et perspectives: 3-19. Laval: Les Presses de l'Université de Laval.

Herbst, T. 2007. Linguistics: Concepts and Ideas for the Description of English. Erlangen: Alleinvertrieb Mencke-Blaesing.

Idiata, D.F. and L. de Nadaillac. 2010. Dictionnaire Isangu-Français. Libreville: Les Éditions du CENAREST.

Italia, M. 2000. Morphosyntaxe verbale dans des corpus de locuteurs basilectaux au Gabon. Mémoire de maîtrise sous la direction de A. Quéffelec. Université de Provence-Aix-Marseille I.

Kwenzi-Mikala, J.T. 1990. Quel avenir pour les langues gabonaises? Revue Gabonaise des Sciences de l'Homme 2: 121-124.

Martin, W. 1996. Lexicographic Resources in a Multilingual Environment: An Orientation. Lexicography as a Financial Asset in a Multilingual South Africa: 9-24. Pretoria: Department of Arts, Culture, Science and Technology.

Matthews, P.H. 1997. The Concise Oxford Dictionary of Linguistics. Oxford: Oxford University Press.

Mavoungou, P.A. 2002. Vers un dictionnaire du français du Gabon. Emejulu, J.D. (Ed.). 2002: Éléments de lexicographie gabonaise. Tome II: 230-262. New York: Jimacs-Hillman Publishers.

Mavoungou, P.A. 2011. Regard sur les onomastismes dans le français de Libreville et leur traitement lexicographique. Mbaandza Revue d'étude et d'analyse francophones 1: 21-50.

Mavoungou, P.A. et al. 2002. Vers un Dictionnaire du Français du Gabon (Premier dictionnaire parallèle contenant une centaine d'articles traités). Unpublished Document. Stellenbosch: University of Stellenbosch.

Mavoungou, P.A. and B. Plumel. 2010. Dictionnaire Yilumbu-Français. Libreville: Les Éditions Raponda Walker. 
Mavoungou, P.A., F. Moussounda Ibouanga and J.A. Pambou. Forthcoming. Dictionnaire des Collocations et Locutions figurées du Français du Gabon.

Mickala Manfoumbi, R. 2004. Lexique pove-français/français-pove. Libreville: Éditions RapondaWalker.

Moussounda Ibouanga, F. 2006. Les Molvilois et leurs langues: dynamiques linguistiques à Mouila de 1900 à nos jours. Thèse de Doctorat Nouveau Régime. Aix-en-Provence: Université Aix-Marseille I-Université de Provence.

Moussounda Ibouanga, F. 2011. Français du Gabon: Approches sociolinguistique et lexicographique (le toli bangando). Paris: Éditions Universitaires Européennes (EUE).

Ndinga-Koumba-Binza, Hugues Steve. 2005a. Considering a Lexicographic Plan for Gabon within the Gabonese Language Landscape. Lexikos 15: 132-150.

Ndinga-Koumba-Binza, Hugues Steve. 2005b. Gabonese Language Landscape: Survey and Perspectives. South African Journal of African Languages 25(3): 97-116.

Ndinga-Koumba-Binza, H.S. 2007. Gabonese Language Landscape: Survey and Perspectives. South African Journal of African Languages 27(3): 97-116.

Ntsaga-Oyouni, S. 1998. Approche de quelques traits du français parlé de jeunes Gabonais habitant la région parisienne. Mémoire sous la direction de S. Lafage. Paris: Université de Paris III-Sorbonne Nouvelle.

Ompoussa, V. 2008. Les particularités lexicales dans le français scolaire au Gabon: le cas de la ville de PortGentil. Thèse de Doctorat Nouveau Régime. Grenoble: Université Stendhal-Grenoble III.

Pourtier, R. 1989. Le Gabon. Tome I: Espace, histoire, société. Tome II: État et développement. Paris: L'Harmattan.

Raponda-Walker, A. 1910. Au pays des Ishogo, simple récit de voyage. Publié Messager du St-Esprit, repris Libreville: Fondation Raponda-Walker, Classiques Africains, 1993.

Raponda-Walker, André and Roger Sillans. 1996. Plantes utiles du Gabon: essai d'inventaire et de concordance des noms vernaculaires et scientifiques des plantes spontanées et introduites du Gabon. Paris: Lechevalier.

Saint-Yves, Gabrielle. 2001. Lexicographic Revolution in Quebec. [online]. Toronto: Lexperimenta. Available: http://www.chass.utoronto.ca/ wulfric/articles/saint-yves2/.

Thibaudier, C. 1991. Contribution à une étude des néologismes dans la presse gabonaise. Mémoire sous la direction de S. Lafage. Paris: Université de la Sorbonne Nouvelle.

UNESCO-LUTO. 2006. Lexique du Kóya (langue des Pygmées du Nord-Est du Gabon). Libreville: Éditions UNESCO.

Van der Veen, L.J. and S. Bodinga-bwa-Bodinga. 2002. Gedandedi sa geviya/Dictionnaire geviyafrançais. Louvain/Paris/Sterling, Virginia: Peeters.

Wiegand, Herbert Ernst. 1998. Wörterbuchforschung. Untersuchungen zur Wörterbuchbenutzung, zur Theorie, Geschichte, Kritik und Automatisierung der Lexikographie. Volume 1. With 159 Illustrations in Text. Berlin/New York: Walter de Gruyter. 


\section{Addendum (Mavoungou et al., forthcoming)}

bord de mer [bordmer] n.m. Milieu géographique abritant nombre de quartiers huppés et sièges administratifs de la capitale, y compris la Présidence de la République $\bullet$ Aworet vit au bord de mer. palais du bord de mer (on dit également le bord de mer = siège de la Présidence de la République). Tous les leaders des partis politiques ont été reçus au palais du bord de mer afin de discuter des nouvelles modalités des prochaines échéances électorales. Les ambassadeurs accrédités au Gabon ont présenté leurs lettres de créances au palais du bord de mer.

clando [klñdo] n.m. PL. clandos. 1. Moyen de transport utilisé illicitement pour l'acheminement des personnes et des biens, généralement, sur une distance assez longue Makaya a emprunté un clando pour se rendre à Kango. Pour boucler ses fins de mois, Abessolo a décidé de faire du clando. Suite au mouvement de grève déclenché par les taximen de Libreville et de Port-Gentil, on pratique la débrouille: on prend le clando. Moussounda qui tient un commerce de friperie à Ntoum prend le clando régulièrement et paie 5000 Fcfa pour chaque ballot. 2 . Personne qui vit de la profession de clando (Voir clandoman). C'est un clando, il n'a rien à t'offrir. $\$. adv. De façon clandestine. Il est parti clando (= filer à l'anglaise).

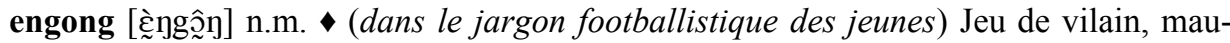
vais jeu $•$ Dépité par le but encaissé, les jeunes de l'équipe adverse ont décidé de jouer engong! Toutes les femmes d'Engong émancipées, il en fit toutes et sans exception ses femmes, ses femmes sans pour autant être mariées légalement avec l'une d'elles (NDONG MBENG, 1992: 73-74). Engong! Engong! Engong! (tube populaire d'un groupe de la place: Raboon). E Engong est un terme populaire du français du Gabon tiré de l'épopée Mvet. Il désigne plus précisément le peuple et le pays des Immortels, redoutables et puissants guerriers. Dans le Nord-Gabon à l'origine et aujourd'hui dans la quasi-totalité du pays, ce terme est utilisé par les jeunes en particulier pour faire référence à un duel physique par analogie à l'esprit belliqueux qui caractérise nombre de guerriers d'Engong en tête desquels se trouve le célèbre Akoma Mba. Voir mvet.

\section{Reference}

Ndong Mbeng, H.F. 1992. Les matitis, mes pauvres.univers en contre-plaqué, en planche et en tôle. St Maur: Éditions Sépia. 